\title{
Effect of lysine supplementation on hypertensive men and women in selected peri-urban community in Ghana
}

\author{
Frederick Vuvor ${ }^{1 *}$, Husein Mohammed ${ }^{2}$, Thomas Ndanu ${ }^{3}$ and Obed Harrison ${ }^{1}$
}

\begin{abstract}
Background: Lysine is one of the essential amino acids and in cereal based diets it is known to be the most limiting and therefore determines the quality of dietary protein in such diets. This study investigated the effect of lysine supplementation on blood pressure of hypertensive adults in selected peri-urban community in Accra, Ghana.

Methods: The study was a randomized double-blind controlled study made up of adults men and women assigned to a lysine supplemented group and a placebo-supplemented (control) group. The subjects aged between $18-45$ years and totaling 180.

Results: Total of 50 (28\%) of the participating were hypertensive defined as Systolic Blood Pressure (SBP) $\geq 140 \mathrm{mmHg}$. The mean SBP of lysine-supplemented group significantly dropped from $146.11 \pm 11.92$ to $128.95 \pm 10.44 \mathrm{mmHg}$ ( $p=0.02$ ). That of women also dropped from $144.12 \pm 10.41$ to $132.28 \pm 10.69 \mathrm{mmHg},(p=0.06$ while the control group had there SBP remained fairly constant after 112 days of intervention with changes in men from $145.79 \pm 12.56$ to $142.79 \pm 11.07 \mathrm{mmHg}(p=0.32)$ and women in the control had very little drop from $145.15 \pm 14.79$ to $145.00 \pm 17$. $93 \mathrm{mmHg}(p=0.96)$.
\end{abstract}

Conclusion: Lysine supplementation resulted in normalization/reduction of blood pressure of hypertensive subjects who have suboptimal lysine intake.

Keywords: Lysine, Hypertension, Placebo, Supplementation

\section{Background}

There are about nine essential amino acids of which lysine is the most limiting, especially in cereal based foods and therefore affects the dietary protein quality. Studies have shown that dietary inadequacy of lysine leads to nonspecific indications of protein deficiency such as low resistance to disease, stress [1,2]. The risk of lysine inadequacy is mostly found in regions where low socioeconomic groups depend on traditional roots, tubers and cereals for their protein supply [1,2]. Many foods supply lysine, but the richest sources include red meats, fish, brewer's yeast, and dairy products. Vegetables, on the other hand, are generally poor sources of lysine, with the exception of legumes. Evidence of the nutritional and

\footnotetext{
* Correspondence: fredvuvor@yahoo.com

${ }^{1}$ Department of Nutrition and Food Science, School of Biological Sciences, College of Basic and Applied Sciences, University of Ghana, Accra, Ghana Full list of author information is available at the end of the article
}

health benefits of increased lysine content of cereal based foods is unlimited [3].

The majority of the deprived and undernourished populations in the world subsist on diets heavily based on cereals [4]. Such diets may probably be low in a number of essential nutrients including lysine. Comparisons about food availability data from various countries revealed that, there are significant decreases in the availability and affordability of animal-sourced foods and there is increased dependence on cereal-sourced foods. Study indicates that, lysine is the amino acid for which the largest differences occur between the diets of the rich and the poor [4].

Analysis conducted on data from 183 countries using food balance sheet has shown that there are high prevalence of lysine deficiency in most West African countries including Ghana [5]. Mean lysine in $\mathrm{mg} / \mathrm{g}$ protein ranges from $43 \mathrm{mg} /$ g protein to $34 \mathrm{mg} / \mathrm{g}$ protein. An average value below the adult male requirement of $45 \mathrm{mg} / \mathrm{g}$ protein indicates health 
risk for such populations. This is due to the fact that many of the most vulnerable are likely to have poorer quality diet (i.e. a greater dependence on cereal) [2]. The Ghanaian mean lysine was estimated to be $41.1 \mathrm{mg} / \mathrm{g}$ protein.

Though agricultural households in the peri-urban areas produce legumes and animals that could be used for household consumption, due to high market prices for these products, most households would prefer to sell them and purchase cheaper foods which are cereals, roots and tubers to feed their families [6]. The rate of malnutrition and morbidity are many times higher in peri-urban areas than in relatively more advantageous urban localities and even rural communities [6]. Animal and legumes protein that could supplement the amino acid pattern of cereals, are expensive for these groups [3].

Lysine is a constituent of a procedure proposed and implemented by Linus Pauling for the management of heart diseases. According to the outcome of his study, "when there are extra amount of lysine and proline in blood, the lipoprotein-(a) attachment sites get obstructed by lysine, creating a "Teflon-like" coating around the lipoprotein particles and hence prevents the lipoprotein-(a) from binding to the arterial walls. Therefore, lysine prevents plaque build-up and then initiates the setback of plaque deposits and invariably prevents pressure build up in the arteries and hence reduce hypertension" [7].

This lysine supplementation trial looked at the effects of lysine supplementation on blood pressure of hypertensive adults in selected peri urban community of Accra, Ghana. It was based on a hypothesis that supplementation of lysine in the diet of hypertensive subjects would significantly reduce or normalized their blood pressures.

\section{Methods}

Sample size determination was done at the household level. This involved enrollment of equal number of men and woman pairs in each group. A total of 30 (15 were men and 15 women) in the placebo group and 30 (15 were men and 15 women) in the lysine group was arrived at. However, the sample size was increased to 45 males and 45 females to give 90 participants in each group making a total of 180 from 90 households containing one man and one woman from each household [4].

Exactly 428 households made up of 856 individuals were screened for eligibility. To be eligible, participants were supposed to be between the ages $18-45$ years and should not be on any anti-hypertensive medications. Of these (428), 90 households totaling 180 individuals of 90 men and 90 women were recruited. Each household was randomly placed in the lysine or placebo group. Randomization was done at the household level to prevent supplements (lysine or placebo) from mixing between household members. The study was a double-blind and the supplements were identical in appearance.
The study protocol was approved by Ethical Review Board of Noguchi Memorial Institute for Medical Research (FWA 00001824-IRB000176). Informed consent form was signed by each recruited household head. The intervention (lysine supplemented) group consumed $1000 \mathrm{mg}$ of lysine per day in two divided doses for a period of 112 continuous days.

Based on the calculations of Pellett [2], it is noted that at $41.1 \mathrm{mg}$ lysine /g protein, lysine availability in Ghanaian diets is low. Table 1 shows the supplementary lysine required to complete the protein quality. An extra $15.2 \mathrm{mg}$ lysine/g protein or $900 \mathrm{mg}$ of lysine per day was needed to supplement the diets of Ghanaians. The lysine was provided in tablet form. Each subject was supplied two tablets of lysine- $\mathrm{HCl}$ (each tablet equivalent to $500 \mathrm{mg}$ lysine per tablet or $500 \mathrm{mg}$ of di-calcium phosphate as a placebo) per day for 112 days. Supplements were formulated by Disto Pharmaceuticals, in Hyderabad.

Lysine mg/g Protein from the formula: Lysine values in milligrams per day were calculated from the equation: Lysine $=(86.3 \times \mathrm{APg} /$ day $)+(19.8 \times \mathrm{CPg} /$ day $)+(63.6 \times P S g)$ day) +599 where AP, CP and PS were animal, cereal and pulse-soy protein respectively. Lysine values in milligrams per gram of protein were derived by further dividing by the amount of total protein [5] FAO/FAOSTAT (2004) (Adapted from Pellett 2004).

Information collected at starting point included: dietary, anthropometry and blood pressure (BP) measurements. A repeated 24-h dietary recall was done for 3 non-consecutive days for each subject including one weekend to obtain a representative data on dietary intake. For the $24 \mathrm{~h}$ recall, the participants were asked to mention all the foods they had consumed in the past $24 \mathrm{~h}$ prior to the interview. With the help of food models they were made to estimate the quantities or portions they consumed and with the help of food composition tables, their nutrient intake was estimated Blood plasma lysine is known to be poor indicator of dietary lysine status thus only dietary information was used to determine lysine levels [8].

Table 1 Lysine requirement and addition calculation for Ghana

\begin{tabular}{ll}
\hline & Unit per capita \\
\hline Lysine $^{a}$ & $\mathrm{mg} /$ day $=2240$ \\
Lysine $^{\mathrm{a}}$ & $\mathrm{mg} / \mathrm{g}=41.1$ \\
Current recommended lysine value & $\mathrm{mg} / \mathrm{g}$ protein $=45.0$ \\
Addition 25\% & Buffer $=56.3$ \\
Lysine to be added & $\mathrm{mg} / \mathrm{g}=15.2$ \\
Total lysine needed & $\mathrm{mg} / \mathrm{day}=826$ \\
Total Lysine to be added & $\mathrm{mg}$ per day $=908$ \\
Total Lysine HCL & $\mathrm{mg}$ per day $=1135$ \\
\hline
\end{tabular}

${ }^{\mathrm{a}}$ Source: [5] FAO/Faostat (2004). Data for 2001. (Adapted from Pellett 2004) 
Dietary data were converted into nutrient content using Ghanaian Food Composition Tables and [9] supplemented by US Department of Agriculture Table [10], owing to absence of amino acid data in the 'Ghanaian Food Composition Tables'. Nutrient examination included type of protein (animal, legume, vegetable and roots and tubers), utilizable protein levels based on the PDCAAS (Protein Digestibility Corrected Amino Acid Score) method and expressed as total utilizable protein per day and utilizable protein $\mathrm{g} / \mathrm{kg}$ body weight, lysine, sulphur amino acids, threonine and tryptophan ( $\mathrm{mg} /$ day and $\mathrm{mg} / \mathrm{g}$ protein), total energy, carbohydrate and fat.

Adequacy of nutrients intake was assessed using FAO/WHO Recommended Dietary Allowance (RDA) and Estimated Average Requirements (EAR) [5]. Adequacy of nutrient intake were determined employing the EAR cut-point method [11] to evaluate the nutrients adequacy of subjects. The population prevalence of inadequacy of a given nutrient is the proportion of the population with intakes below the EAR [12]. Nutrients intakes were compared to the RDAs for each subject. Protein intakes were categorized by sources namely cereal protein, legume protein, animal protein, protein from fruits and vegetables, protein from roots and tubers, and protein from other plant sources. Energy intakes were expressed as the percentage contributions from the various sources namely carbohydrate, protein and fats.

All the anthropometric measurements including weight and height were collected using standard procedures. Weight and height were taken using the weighing scale and Stadiometer respectively. Body Mass Index (BMI) was calculated as weight in kilograms divided by the square of height in meters. Clinical assessments involved the determination of BP before and after supplementation/intervention. Blood pressure was recorded using a digital sphygmomanometer. Here, the participants were made to relax and sit comfortably. It was made sure that participants had recently emptied their bladder prior to the measurement. Tight sleeved clothing were removed and lose ones were rolled up. They were made to rest in a chair next to a table for about 5$10 \mathrm{~min}$. Their left arm was gently positioned at heart level with palm facing up. Seated up straight with legs uncrossed and forearm on the table, the arm cuff was wrapped around it. The start button of the sphygmomanometer was pressed and the reading were recorded with alongside with the date and time after the automated process. All measurements were done in triplicates and their averages were used. A subject was classified as hypertensive if SBP $\geq 140 \mathrm{mmHg}$ (systolic $\mathrm{BP})$. The design of the monitoring was such that the tablets were provided on a weekly basis during the intervention period.
Epi-Info 2000, MS Excel 2007 and SPSS version 16 were used for data analyses. Statistical analysis included comparisons between groups for differences in diets, anthropometry and blood pressure. Data analysis was carried out using paired and independent t-test for comparison of measured parameters followed by analysis of variance (ANOVA). Changes in BP (Delta) values were calculated for both men and women groups (lysine and placebo). The chi-square test was used for comparison of categorical variables between the two treatment groups. Significance level was set at 0.05. An unpaired t-test was employed to compare the lysine-supplemented and the placebo-supplemented subjects. The paired t-test was used to compare the delta of baseline and posttest data of all categories (normotensive, and hypertensive).

\section{Results}

\section{Background characteristics}

More than $50 \%$ of the participating men were artisans, while more than $60 \%$ of the women were food vendors.

\section{The baseline characteristics}

Table 2 shows that, at the start of the study all subject and conditions were fairly similar and comparable.

\section{Dietary intakes among the study groups}

Examining the differences in habitual dietary intakes by treatment type showed that there was no differences in energy, total and utilizable protein, and lysine (in both $\mathrm{mg} / \mathrm{kg}$ body weight and $\mathrm{mg} / \mathrm{g}$ protein) among all the groups. Adding of $1000 \mathrm{mg}$ lysine accounted for $0.19 \mathrm{~g}$ of $\mathrm{N}$ which accounted for $2.3 \%$ in men, $2.7 \%$ in women based on their habitual intake (Table 3 ). This percentage increase did not significantly add to the overall nitrogen in the lysine versus control group (Table 3); but led to a reduction in risk of protein and lysine inadequacy in the group (Table 3 ).

In some other parts of the developing world, cereals have been reported as the major source of dietary protein; an example is rural Bangladesh where cereals contribute up to $53 \%$ of total protein intake [13]. The proportions of proteins contributed by the different food groups have implications on the protein quality. Animal proteins are known to be of a higher quality than plant proteins because they contain all the essential amino acids unlike plants foods which do not.

Examining the amino acid balance (Table 4) in comparison with 'WHO reference pattern' revealed that, before the supplementation, women and men in the placebo and lysine group met all amino acids (total sulfur amino acids, threonine and tryptophan) reference pattern [14] but not the lysine. Adding lysine enhanced the lysine score but it did not make any other amino acid limiting which is a function of amino acid score. 
Table 2 Characteristics of subjects at baseline

\begin{tabular}{lllll}
\hline Variable & Men & & Women \\
\cline { 2 - 3 } & $\begin{array}{l}\text { Lysine } \\
(n=46)\end{array}$ & $\begin{array}{l}\text { Placebo1, } \\
(n=44)\end{array}$ & $\begin{array}{l}\text { Lysine1,4 } \\
(n=46)\end{array}$ & $\begin{array}{l}\text { Placebo1,4 } \\
(n=44)\end{array}$ \\
\hline Age y & $33.2 \pm 8.2$ & $33.5 \pm 7.7$ & $31.4 \pm 7.0$ & $32.2 \pm 6.6$ \\
Body Mass Index kg/m2 & $22.60 \pm 3.41$ & $22.43 \pm 3.09$ & $25.67 \pm 5.28$ & $27.64 \pm 5.76$ \\
\hline
\end{tabular}

${ }^{\mathrm{a}}$ Mean \pm SD (all such values). ${ }^{\mathrm{b}}$ None of the values were significantly different at $p \leq 0.05$

\section{Blood pressure}

At baseline, $41 \%$ of males and $17 \%$ of females in the lysine group were hypertensive whereas in the placebo group, $43 \%$ of males and $29 \%$ of females were hypertensive. There was no significant difference between the lysine and placebo groups at baseline. Generally lysine supplementation resulted in a reduction in SBP of hypertensive subjects. The mean changes in SBP levels of subjects at baseline and at post supplementation were compared. Hypertensive was defined as SBP $\geq 140 \mathrm{mmHg}$. The results in Table 5 shows a reduction /normalization of SBP in lysinesupplemented hypertensive groups but not in the control groups. Also no significant change was observed in men and women who were normotensives (SBP < $140 \mathrm{mmHg}$ ).

\section{Discussion}

The greatest proportion of household heads (38\%) were artisans. This was in line with the fact that several construction works were going on in the study area, thus creating job opportunities for carpenters, masons and the like. The study indicates that energy intake was generally low among study participants with all age group having a mean energy intake below the RDA. Meeting energy requirements has been a problem in developing countries. The fact still remains that over 300 million people in Africa consume less than $2100 \mathrm{cal}$ per day on average [10].

On the contrary protein intake was found to be quite adequate among study participants. About $70 \%$ of subjects met their EAR for proteins and all age groups had average intake values $>60 \%$ of the RDA. This may be attributed to the availability of animal sourced foods, particularly fish, meat and eggs in the study area. This observation is contrary to expectation since protein deficiency is one major nutritional problem in Ghana. It however implies that nutritional problems in the country differ from community to community and thus intervention programmes should be based on findings in different communities. Among women however, a high proportion (47.7\%) had inadequate protein intakes (intake less than their EAR). There is also the likelihood that some subject over-reported their intake of protein-rich foods since frequent consumption

Table 3 Dietary intakes among the study groups at baseline

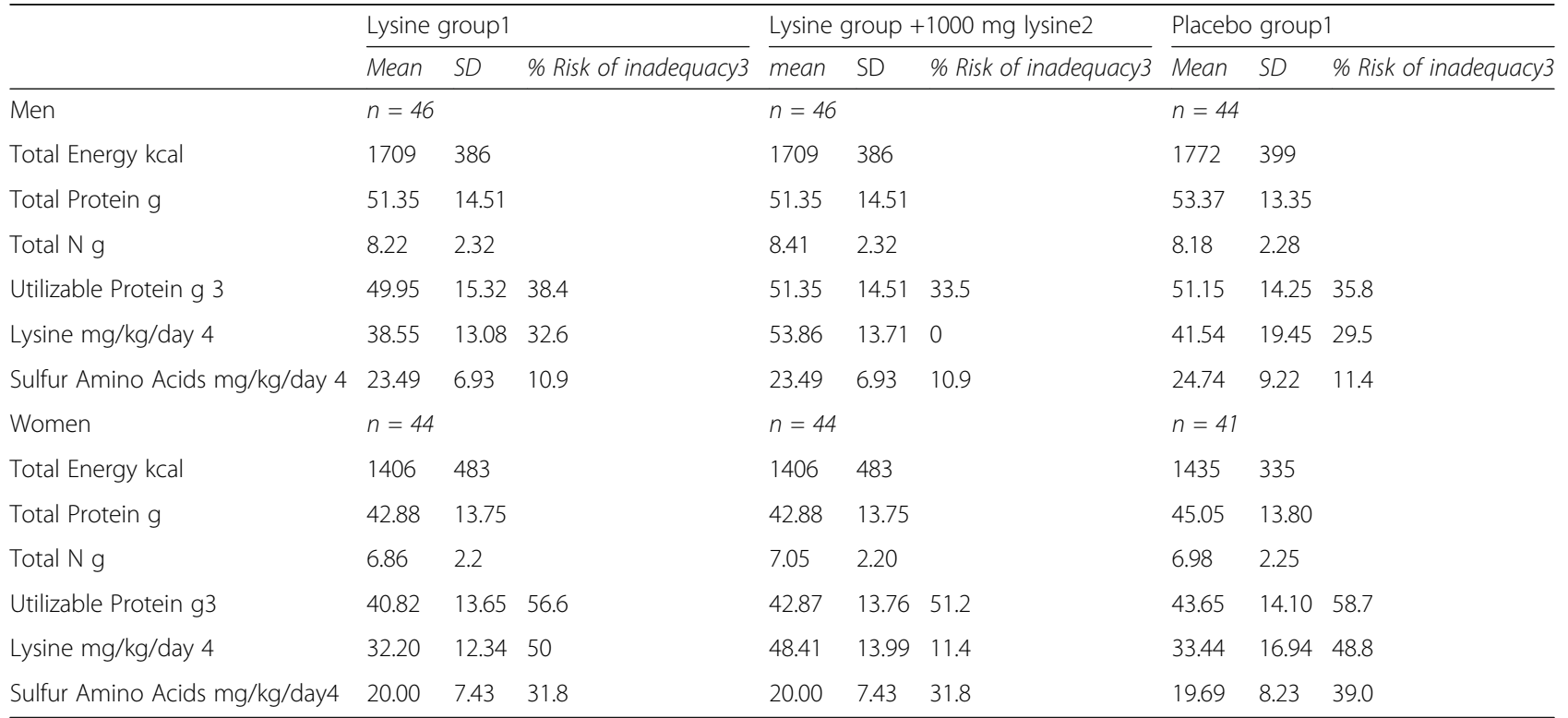

No significant differences in the lysine and control groups before adding lysine tested using independent sample t-test The group reveals the expected enhancement in baseline value of the lysine group nutrients on adding 1000 mg of lysine which is corresponding to the quantity of supplement supplied

Percent at risk of protein deficiency, based on a requirement of protein of $0.66 \mathrm{~g} / \mathrm{kg}$ intended for adults (WHO, 2007)

Adult amino acid requirements: $30 \mathrm{mg} / \mathrm{kg} /$ day lysine, $15 \mathrm{mg} / \mathrm{kg} /$ day sulfur amino acids, $15 \mathrm{mg} / \mathrm{kg} /$ day threonine, $4 \mathrm{mg} / \mathrm{kg} /$ day tryptophan (WHO, 2007)

Difference from placebo group, $p<0.001$ 
Table 4 The amino acid balance in comparison to WHO 2007 reference and on the addition of 1000 mg of supplement at baseline

\begin{tabular}{|c|c|c|c|c|c|c|c|c|c|}
\hline & \multicolumn{3}{|c|}{ Lysine 1} & \multicolumn{3}{|c|}{ Lysine +1000 mg lysine } & \multicolumn{3}{|c|}{ Placebo1 } \\
\hline & $\overline{\text { Mean }}$ & $S D$ & $\begin{array}{l}\text { Percent below reference } \\
\text { pattern }\end{array}$ & mean & SD & $\begin{array}{l}\text { Percent below reference } \\
\text { pattern }\end{array}$ & Mean & SD & $\begin{array}{l}\text { Percent below reference } \\
\text { pattern }\end{array}$ \\
\hline$\overline{M e n}$ & $n=46$ & & & $n=46$ & & & $n=44$ & & \\
\hline Lysine mg/g protein 3 & 55.59 & 7.76 & 10.9 & $\begin{array}{l}79.47 \\
2\end{array}$ & 9.87 & 0 & 55.78 & 9.57 & 13.6 \\
\hline $\begin{array}{l}\text { Sulfur Amino Acids mg/g } \\
\text { protein3 }\end{array}$ & 34.12 & 2.84 & 0 & 34.12 & 2.84 & 0 & 33.76 & 3.16 & 0 \\
\hline Women & $n=44$ & & & $n=44$ & & & $n=41$ & & \\
\hline Lysine $\mathrm{mg} / \mathrm{g}$ protein 3 & 53.01 & 7.29 & 15.9 & 81.962 & 11.15 & 0 & 55.28 & 9.04 & 9.8 \\
\hline $\begin{array}{l}\text { Sulfur Amino Acids mg/g } \\
\text { protein3 }\end{array}$ & 32.82 & 3.31 & 0 & 32.82 & 3.31 & 0 & 32.99 & 3.36 & 0 \\
\hline
\end{tabular}

protein3

No significant differences between dietary intakes in the lysine and control groups before adding lysine tested using independent sample t-tests

This group reflects the expected improvement in baseline nutrient value of the lysine group diets upon the addition of 1000 mg of lysine which is equivalent to the amount of supplement provided

Adult amino acid reference pattern: $45 \mathrm{mg} / \mathrm{g}$ protein lysine, $22 \mathrm{mg} / \mathrm{g}$ protein sulfur amino acids, $23 \mathrm{mg} / \mathrm{g}$ protein threonine, $6 \mathrm{mg} / \mathrm{g}$ protein tryptophanTable 5 : Effects of lysine supplementation on the BP of hypertensive participants enrolled in the study

of such foods including fish, meat and eggs are seen as an indicator of wealth.

Our findings further showed that nearly equal proportions of total protein intakes came from cereals and animal foods (Fig. 1). Main animal foods found in the diets of subjects were fishes, although meats and eggs were also present in significant amounts. This confirms that among people living in the coastal regions, fish constitutes about $60 \%$ of animal protein intake (National Fisheries Association of Ghana, 2004). The high proportion of proteins from cereals may be attributed to the frequent consumption of these foods and their products in the study population. Cereal products such as maize and rice, were consumed nearly daily by study participants (Fig. 2). Thus protein quality among study participants can be said to be quite adequate. Lysine is the first limiting amino acid in nearly all underdeveloped countries and certainly, about $30 \%$ of men and $50 \%$ of women are deficient of lysine $(\mathrm{mg} / \mathrm{kg} /$ day) $[15,16]$.

Energy intake among subjects was generally inadequate. Hypertension was higher in males than females $(p=0.023)$. Using the paired sample t-test our data shows that the lysine supplementation resulted in a significant reduction in $\mathrm{BP}$ of hypertensive men $(P=0.024)$ but there was no other changes in BP in both men and women hypertensive among the control group.

After 112 days of intervention lysine-supplemented group recorded a significantly lower variation in SBP than the placebo supplemented group. Results from Hussain et al., (2004) and Smriga et al., (2004) [3, 4] have shown that some stress responses in low economic populations consuming mainly cereal diets can be enhanced with lysine supplementation.

About $28 \%$ of the participating subjects were hypertensive. The mean SBP of hypertensive men significantly dropped from $146.11 \pm 11.93$ to $128.95 \pm 10.44 \mathrm{mmHg}$ $(p=0.02)$, while the women dropped from144.12 \pm 10.41 to $132.38 \pm 10.69 \mathrm{mmHg}(p=0.06)$. The change in men on control was from $145.79 \pm 12.56$ to $142.79 \pm 11.07 \mathrm{mmHg}$ $(p=0.32)$ and women on control from145.15 \pm 14.79 to $145.00 \pm 17.93 \mathrm{mmHg}(p=0.96)$. This study revealed that adequate lysine intake could significantly reduce the BP of hypertensive patients especially those on low lysine diets.

The granular neurons in the cerebral cortex of the brain are of two types, one functions as excitatory while other as inhibitory neurotransmitters mainly [17]. Glutamate serves as excitatory and gamma-aminobutyric acid (GABA) functions as inhibitory neurotransmitters [17]. Lysine is directly

Table 5 Effects of lysine supplementation on the BP of hypertensive participants enrolled in the study

\begin{tabular}{|c|c|c|c|c|c|c|c|c|}
\hline & \multicolumn{3}{|l|}{ Lysine1 } & \multirow[t]{2}{*}{$p$-value } & \multicolumn{3}{|l|}{ Control1 } & \multirow[t]{2}{*}{$p$-value } \\
\hline & Baseline & Posttest & Change & & Baseline & Posttest & Change & \\
\hline \multicolumn{9}{|l|}{ Men } \\
\hline n3 & 19 & 19 & 19 & & 19 & 19 & 19 & \\
\hline Systolic (mmHg) & $146.11 \pm 11.932$ & $128.95 \pm 10.44$ & $7.16 \pm 12.65^{*}$ & 0.02 & $145.79 \pm 12.56$ & $142.79 \pm 11.07$ & $3.00 \pm 12.87$ & 0.32 \\
\hline \multicolumn{9}{|l|}{ Women } \\
\hline n3 & 8 & 8 & 8 & & 13 & 13 & 13 & \\
\hline Systolic (mmHg) & $144.12 \pm 10.41$ & $132.38 \pm 10.69$ & $5.75 \pm 7.02$ & 0.06 & $145.15 \pm 14.79$ & $145.00 \pm 17.93$ & $0.15 \pm 11.48$ & 0.96 \\
\hline
\end{tabular}

Paired-sample $t$ tests: Mean \pm SD (all such values): Sample size: ${ }^{*} P<0.05$ 


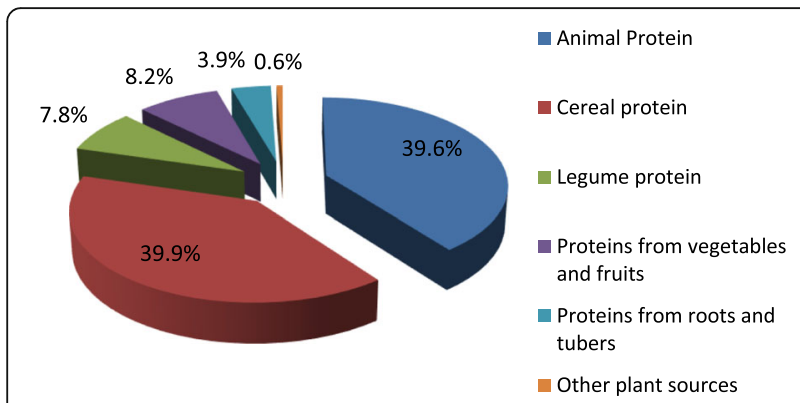

Fig. 1 Shows the percentage distribution of different food groups to protein intake among the participants in the study. Approximately $40 \%$ of the protein intake came from cereals. Animal source foods contributed about $40 \%$ dietary protein intake; legumes contributed just about $8 \%$

involved in the synthesis of GABA and which reduces stress and anxiety [17]. The deficiency of lysine reduces the availability of GABA. It stands to reason that there is a strong relationship between diets low in lysine and high blood pressure which may be due to excess stress/anxiety as a result of low levels of lysine intake.

\section{Strengths and limitations}

This study had several strengths regarding the potential benefit of lysine supplement on improving hypertension; however, other factors related to blood pressure had not been controlled such as whether there were any changes in dietary intakes of the 112 days and also other lifestyle factors. This is a limitation that can be improved upon for further studies.

\section{Conclusions}

The results suggest several possible protective effects of lysine on hypertension. Lysine could directly help reduce BP of hypertensive individuals whose lysine intakes are low. Lysine could also have control over the abnormal responses to stressors/anxiety which is known to influence heart beats and therefore on hypertension. After 112 days of daily intake of $1000 \mathrm{mg}$ of lysine, lysinesupplemented group recorded a significant reduction in

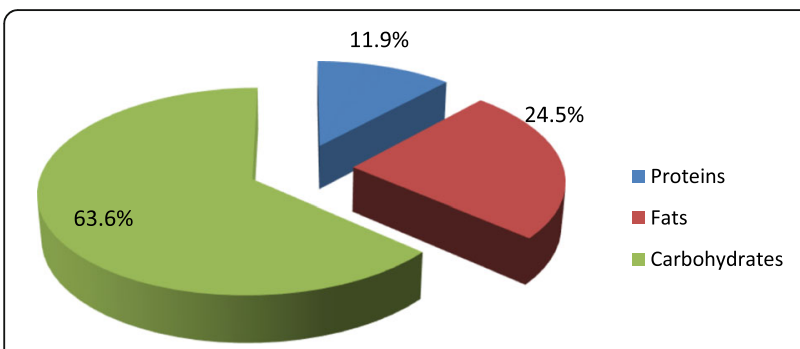

Fig. 2 displays the contributions of carbohydrate, protein and fats intake among study participants. Protein contributed about 12\%; carbohydrate about 64\%; and fats contributed $25 \%$ of energy intake
SBP compared with the control hypertensive group. It could be concluded that adequate lysine intake may have possible positive effects on blood pressure of individuals with no underlying secondary causes. These results also suggest that lysine may be a useful nutrient adjunct to hypertension medications.

\section{Abbreviations \\ ANOVA: Analysis of variance; AP: Animal protein; BP: Blood pressure; CP: Cereal protein; EAR: Estimated average requirements; FAO: Food and agriculture organization; GABA: Gamma-aminobutyric acid; PDCAAS: Protein Digestibility Corrected Amino Acid Score; PS: pulse-soy protein; \\ RDA: Recommended dietary allowance; SBP: Systolic blood pressure; \\ SPSS: Statistic package for social sciences; WHO: World health organization}

\section{Acknowledgements}

Authors express their appreciation to the study participants, Chief/elders, Nurses, Pharmacy Assistants, Laboratory Technicians, Teaching/Research Assistants from Prof. Matilda Steiner-Asiedu, Prof. Firibu Kwesi Saalia, Dr. William Bruce Owusu, Prof. Emmanuel Ohene Afoakwa and Dr. Agartha Ohemeng all of the Department of Nutrition and Food Science, University of Ghana for their kind support of this work.

Funding

The project was financially supported by Ajinomoto Company, France.

\section{Availability of data and materials}

Analysis of the dataset used for this study is on-going and therefore we cannot make all our data available at this time.

\section{Authors' contributions}

FV: designed the study, collected the data, analyzed and interpreted the data, drafted the manuscript and revised the paper; HM: design, data acquisition, analyses, interpretation of the results and drafting of the manuscript; TN: analysis, interpretation and revision of the paper and $\mathrm{OH}$ : analysis, interpretation and revision of the paper. All authors read and approved the final manuscript.

Ethics approval and consent to participate

The ethical clearance was obtained from Noguchi Memorial Institute for Medical Research IRB of the University of Ghana. Written consent was sought from each study participant and any information obtained from the study was kept strictly confidential. The study protocol was reviewed and approved by Human Ethical Review Board of Noguchi Memorial Institute for Medical Research (FWA 00001824-IRB000176).

\section{Consent for publication}

Not applicable.

\section{Competing interests}

The authors declare that they have no competing interest.

\section{Publisher's Note}

Springer Nature remains neutral with regard to jurisdictional claims in published maps and institutional affiliations.

\section{Author details}

'Department of Nutrition and Food Science, School of Biological Sciences, College of Basic and Applied Sciences, University of Ghana, Accra, Ghana. ${ }^{2}$ McGill University, Montreal, Canada. ${ }^{3}$ Department of Community and Preventive Dentistry, School of Medicine and Dentistry, College of Health Sciences, University of Ghana Legon-Accra, Accra, Ghana. 
Received: 9 November 2016 Accepted: 19 July 2017

Published online: 27 July 2017

\section{References}

1. Young VR, Pellett PL. Current concepts concerning indispensable amino acid needs in adults and their implications for international nutrition planning. Food Nutr Bull. 1990;12:289-300.

2. Pellett PL, Ghosh S. Lysine fortification: past, present, and future. FOOD AND NUTRITION BULLETIN-UNITED NATIONS UNIVERSITY. 2004;25:107-13.

3. Hussain T, Abbas S, Khan MA, Scrimshaw NS. Lysine fortification of wheat flour improves selected indices of the nutritional status of predominantly cereal-eating families in Pakistan. Food Nutr Bull. 2004;25:114-22.

4. Smriga M, Ghosh S, Mouneimne Y, Pellett PL, Scrimshaw NS. Lysine fortification reduces anxiety and lessens stress in family members in economically weak communities in Northwest Syria. Proc Natl Acad Sci U S A. 2004;101:8285-8.

5. Faostat F. Statistics database. 2004.

6. Maxwell D, Levin C, Armar-Klemesu M, Ruel M, Morris S, Ahiadeke C. Urban livelihoods and food and nutrition security in Greater Accra. Ghana: International Food Policy Research Institute Washington, DC; 2000

7. Pauling L. Case report: Lysine/ascorbate-related amelioration of angina pectoris. J Orthomolecular Med. 1991;6:144-6.

8. Ljungqvist BG, Svanberg U-O, Young V. Plasma amino acid response to single test meals in humans. Res Exp Med. 1978;174:13-28.

9. Eyeson K, Ankrah E. Composition of foods commonly used in Ghana. 1975.

10. Health UDo, Services H. USDA. Dietary Guidelines for Americans 6th Edition. Washington, DC: US Government Printing Office; 2005. p. 2005.

11. De Lauzon B, Volatier J, Martin A. A Monte Carlo simulation to validate the EAR cut-point method for assessing the prevalence of nutrient inadequacy at the population level. Public Health Nutr. 2004;7:893-900.

12. Smolin L, Grosvenor M. Energy balance and weight management, Nutrition Science and Application. 4th ed. London: Wiley; 2003. p. 176-215.

13. Torres A, Willett W, Orav J, Chen L, Huq E. Variability of total energy and protein intake in rural Bangladesh. Implications for epidemiological studies of diet in developing countries. Food Nutr Bull. 1990;12:220-8.

14. Millward DJ, Layman DK, Tomé D, Schaafsma G. Protein quality assessment: impact of expanding understanding of protein and amino acid needs for optimal health. Am J Clin Nutr. 2008;87:1576S-81S.

15. Pellet $P$, Young $V$. Role of meat as a source of protein and essential amino acids in human nutrition. Advances in Meat Research. 1990;6:329-67.

16. WHO. Protein and Amino Acid Requirements in Human Nutrition. In: WHO/ FAO/UNU, editor. . Geneva: World Health Organization; 2007. p. 276.

17. Guyton AC, Hall J. Insulin, glucagon, and diabetes mellitus. Textbook of medical physiology. 2000;8:855-67.

\section{Submit your next manuscript to BioMed Central and we will help you at every step:}

- We accept pre-submission inquiries

- Our selector tool helps you to find the most relevant journal

- We provide round the clock customer support

- Convenient online submission

- Thorough peer review

- Inclusion in PubMed and all major indexing services

- Maximum visibility for your research

Submit your manuscript at www.biomedcentral.com/submit
Biomed Central 